\title{
The Effectiveness of Wenner-Schlumberger and Dipole-dipole Array of 2D Geoelectrical Survey to Detect The Occurring of Groundwater in the Gunung Kidul Karst Aquifer System, Yogyakarta, Indonesia
}

\author{
Oktanius Richard Hermawan and Doni Prakasa Eka Putra* \\ Department of Geological Engineering, Faculty of Engineering, Gadjah Mada University, Yogyakarta, Indonesia
}

\begin{abstract}
Until today, geoelectrical survey is the most effective method for groundwater exploration. 2D method or known as horizontal profiling is now the most appropriate method in the geoelectrical survey compare to vertical electrical sounding method. The 2D method of Wenner-Schlumberger and Dipole-dipole configuration proved to be very effective to locate conventional aquifer occurrence on volcanic terrain or sedimentary terrain. Karst aquifer system is an unconventional aquifer and acts very differ in contrast with the conventional sedimentary aquifer. Heterogeneity and discontinuity of limestones in karst terrain will reveal a wide variety of resistivities, hence it is difficult to interpret. This research has important objective to define the effectiveness of the Wenner-Schlumberger and Dipole-dipole configuration in the 2D geoelectrical survey to explore groundwater in the karst area. Field observation of geology and 2D geoelectrical survey were conducted in underground river of Kali Suci Area, Gunung Kidul. In Kali Suci where an endokarst cave was occured on the surface, line survey was placed in the top of the cave and across the geometry of the cave. Measured stratigraphy in the wall of the cave found four types of limestone which consist of packstone, wackestone, grainstone and crystalline limestone. The Wenner-Schlumberger and Dipole-dipole method can detect differentiation of limestone types and also the exposed underground river successfully. However, compared to Wenner-Schlumberger array, Dipole-dipole array reveals less vertical accuration.. Therefore, on this research, the best method to detect water saturated zone or gourndwater in the karst system is the Wenner-Schlumberger method.
\end{abstract}

Keywords: 2D geoelectrical survey - Wenner-Schlumberger method · Dipole-dipole method $\cdot$ Karst aquifer $\cdot$ Gunung Kidul · Indonesia.

\section{INTRODUCTION}

Karst geological setting causes groundwater tends to accumulate in the gap below the surface in the form of rivers and caves under the ground, this form is classified as an unconventional aquifer. Southern of Gunung Kidul regency located near Yogyakarta, Indonesia is mainly covered by karst landscape called as Gunungsewu region. One significant problem on this region is drought during the dry sea-

\footnotetext{
${ }^{*}$ Corresponding author: D.P.E. PUTRA, Department of Geological Engineering, Gadjah Mada University. Jl. Grafika 2 Yogyakarta, Indonesia. E-mail: email@email.com
}

son and this problem limited the access of water for the community and the development of this region. The drought occur actually due not because of the absence of groundwater, but due to the difficulties to find appropriate location to drill groundwater in the unconventional aquifer in the karst system. According to the BAPPEDA DIY (1991, in Kusumayudha, 2004), from the estimated annual water balance for the Gunungsewu region, about 200 million cubic meters per year of groundwater is available in the area, whereas the need for clean water on Gunung Kidul region is only about 50 million cubic meters per year. That means groundwater 
is not used optimally, as a lot of groundwater flow through underground river and discharge in the border of the sea as seepages and springs or huge outflows such as Baron outflow. Based on the chemistry of water, it is proved that the outflows water near the sea are hydraulically connected with water from inflows of underground rivers located in the Gunung Kidul region northern of the Gunungsewu area (Hastuti, 2015). These above facts show clearly that beneath Gunungsewu area, there are a lot of groundwater or underground rivers.

Until now, gfeoelectrical method is the most effective method for groundwater exploration including in karst terrain because resistivity of rock or sediment layers beneath the surface will be decreased significantly than it should have due to water. 2D method or as known as horizontal profiling is now the most appropriate method in the geoelectrical survey compare to vettical electrical sounding method. The 2D method of Wenner-Schlumberger and Dipoledipole configuration proved to be very effective if it used on volcanic terrain or sedimentary terrain which is the exploration of conventional aquifer. Karst aquifer system is an unconventional aquifer and acts very differ in contrast with conventional sedimentary aquifer. Heterogeneity and discontinuity of limestones in karst terrain will reveal a wide variety of resistivity values, hence it is difficult to interpret.

Regarding the application of 2D geoelectrical survey in karst area, Zhou et al., (2002) has done similar research, but restricted only to prove the best array in detecting caves and sinkholes in the karst system. The result is concluded Dipole-dipole to be the best array in that case of research. On other side, Nugroho and Sukiyah (2016) also conducted a geoelectrical survey around Seropan Cave, Gunung Kidul, Indonesia using Wenner-Schlumberger method. The survey resulted in excellent cross-section which could detect Seropan Cave and its underground river inside. Therefore, what is the most effective method to detect groundwater or underground river in the karst area become an important objective to be answer on this research.

\section{Study Area And Geological Setting}

Research area is located in Kali Suci, Pacarejo, Semanu Districts, Gunung Kidul Regency, Spe- cial Province of Yogyakarta (see Figure 1). Kali Suci is a flowing river in karst areas of Southern Mountain zone. Kali Suci flows from north to south with a width of $\pm 4 \mathrm{~m}$ and a depth that varied from upstream to downstream between $50--230 \mathrm{~cm}$. The river enters a cave geometry downstream of observation stations. The dimension of the cave is 5 meters wide and the height to the ceiling is $\pm 25 \mathrm{~m}$. The measured stratigraphic observations were conducted at coordinates UTM (49S) 460223; 9114651. The location of geoelectrical survey measurement is in the southern part of measured stratigraphic data.

According to Van Bemmelen (1949), the Southern Mountain Zone can be divided into three subzones; Baturagung Subzone, Wonosari Subzone and Gunungsewu Subzone. Wonosari Subzone is a plateau $( \pm 190 \mathrm{~m})$ located in the central part of the Southern Mountain Zone, which is in Wonosari and surrounding areas. The research area is included in Gunungsewu Subzone. Gunungsewu Subzone is a set of hills with landscape of karst system, which means a landscape made of limestone hills forming several conical shape with heights exceed hundred meters. Among the hills, it is possible to find lakes, sink holes and below the surface there is limestone cave and flowing underground river. This karst landscape stretches from Parangtritis beach in the west to Pacitan in the east. Based on Kusumayudha (2000), Gunungsewu Subzone in more detail can be divided into; (1) Karst plain unit, (2) Karst conical hills unit and (3) Coastal plain unit.

The karst plain unit is located in Wonosari Plateau which occupies the middle part of $\mathrm{Gu}$ nungsewu. In general, Wonosari Plateau section has relatively flat topography where the slope is less than $5^{\circ}$ and the average elevation is $120-210 \mathrm{~m}$. Move to the south is the unit of karst conical hills which composed by cone of limestones and known as the Thousand Hills located in the southern part of Gunungsewu. This unit has a topography with an angle of 5$-20^{\circ}$ and an elevation between 75-400 m. Bordered by Indian ocean is the coastal plain unit located in the southern part of Gunungsewu which is a row of beaches. The topography in this unit is flat where the angle of the slope is $0-2^{\circ}$ at an altitude of less than $25 \mathrm{~m}$. 


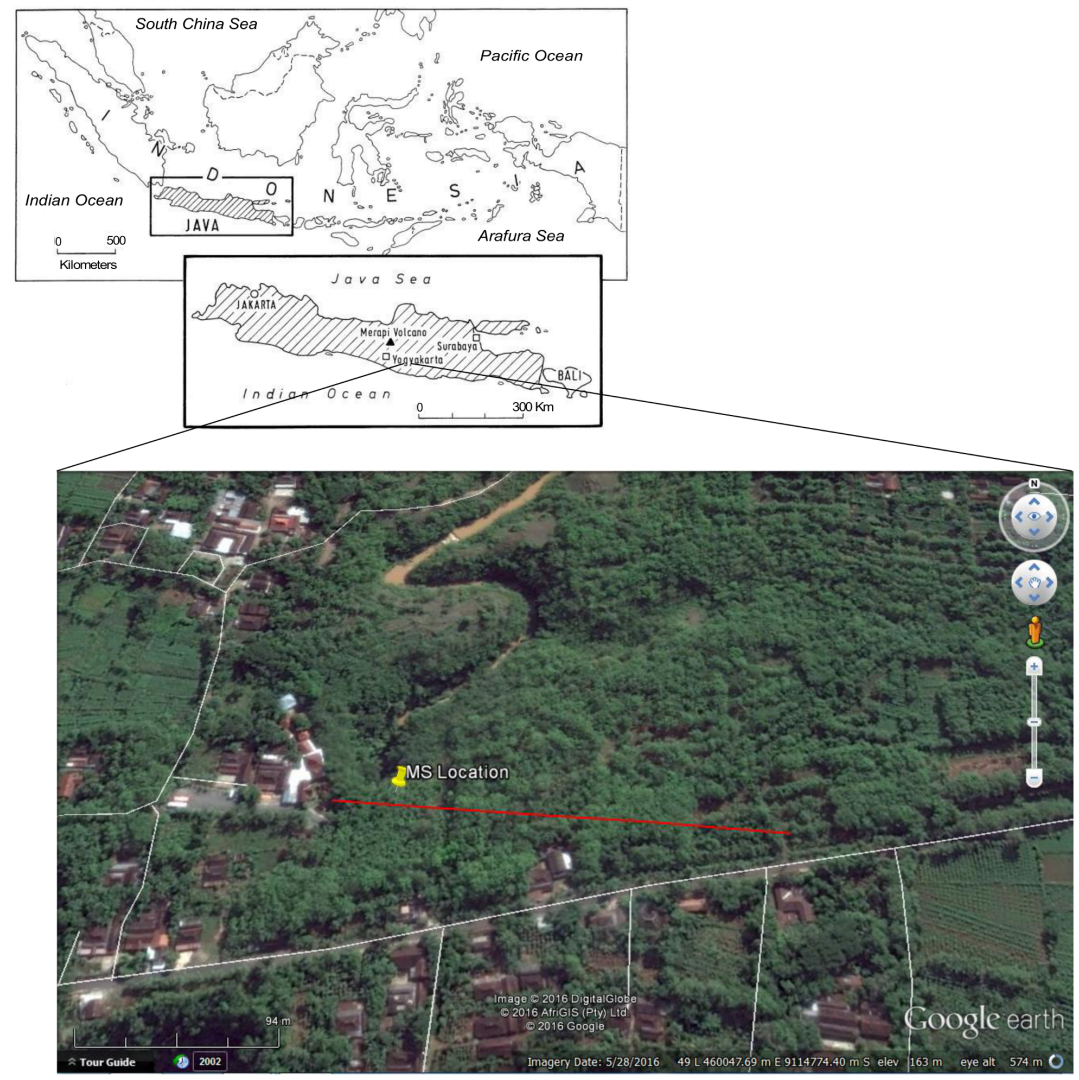

Figure 1: Location of the study area in Kali Suci, Pacarejo, Semanu, Gunung Kidul, Yogyakarta, Indonesia.

There is only one lithology formation that composes research area's stratigraphy, it is Wonosari Formation. Wonosari Formation lays conformably above the Sambipitu Formation. This formation consists of limestones and marl (Surono et al., 1992). Its spread extends almost half of the southern part of the Southern Mountains stretching eastward, turning northward to the eastern hills of Panggung to the west of Wonogiri / Baturetno depression region. Overall, this Wonosari Formation was formed during the Miocene. According to Kusumayudha (2000), limestone of Wonosari Formation on Gunungsewu Subzone can be divided into boundstone, packstone and wackestone (see Table 1).

According to MacDonald \& Partners (1984), regional hydrogeology of study area is belongs to aquifer system of Wonosari Formation. The concept of aquifer in Wonosari Formation can be divided into two; allogenic system called Wonosari Plateau System and authogenic system called Gunungsewu System. The hydrogeological unit of research area specially categorized as Gunungsewu Type (see Figure 2).
On this type, caves and sinkholes are the entrance to the underground river system, but it also found many springs and outflows as a way out. The depth of groundwater in the Wonosari Plateau is shallow, less than $20 \mathrm{~m}$. In the Gunungsewu area, the depth of groundwater or underground river can be found in the range between 50-200 $\mathrm{m}$ below the ground-surface.

\section{THEORITICAL BACKGROUND}

\section{Karst aquifer system}

In general, karst aquifer can be divided into several parts, such as: the upper limit of the surface (exokarst), epikarst, vadose zone, saturated zone and karstification base (Stevanović, 2014). More clearly the element of karst aquifer on schematic arrangement can be seen in Figure 3. First, the top surface or exokarst can contain multiple features, these features have a very important role in the infiltration process of rain water into the aquifer (recharge). At the bottom of exokarst there is epikarst, the outer part of karst system that is found at the top of the vadose zone, partly saturated with water, saving a significant amount of water and proceed the 
Table 1: Limestone facies description in Gunungsewu Subzone (Kusumayudha, 2000).

\section{Lithofacies Description}

1. Boundstone Consists of algae fossil shells $3-7 \mathrm{~cm}$ in diameter and large foraminifera $0.5-3 \mathrm{~cm}$ in size with a growing structure and contains carbonate mud $<10 \%$.

2. Packstone

Composed of large fossil foraminifera shells 0.5 to $3 \mathrm{~cm}$ in diameter, grain supported and contain carbonate mud $<10 \%$.

3. Wackestone

Consisting of large foraminifera fossil shells $0.2-1 \mathrm{~cm}$ in diameter, containing 30-50 \% granules, matrix supported with 50-70\% carbonate mud.

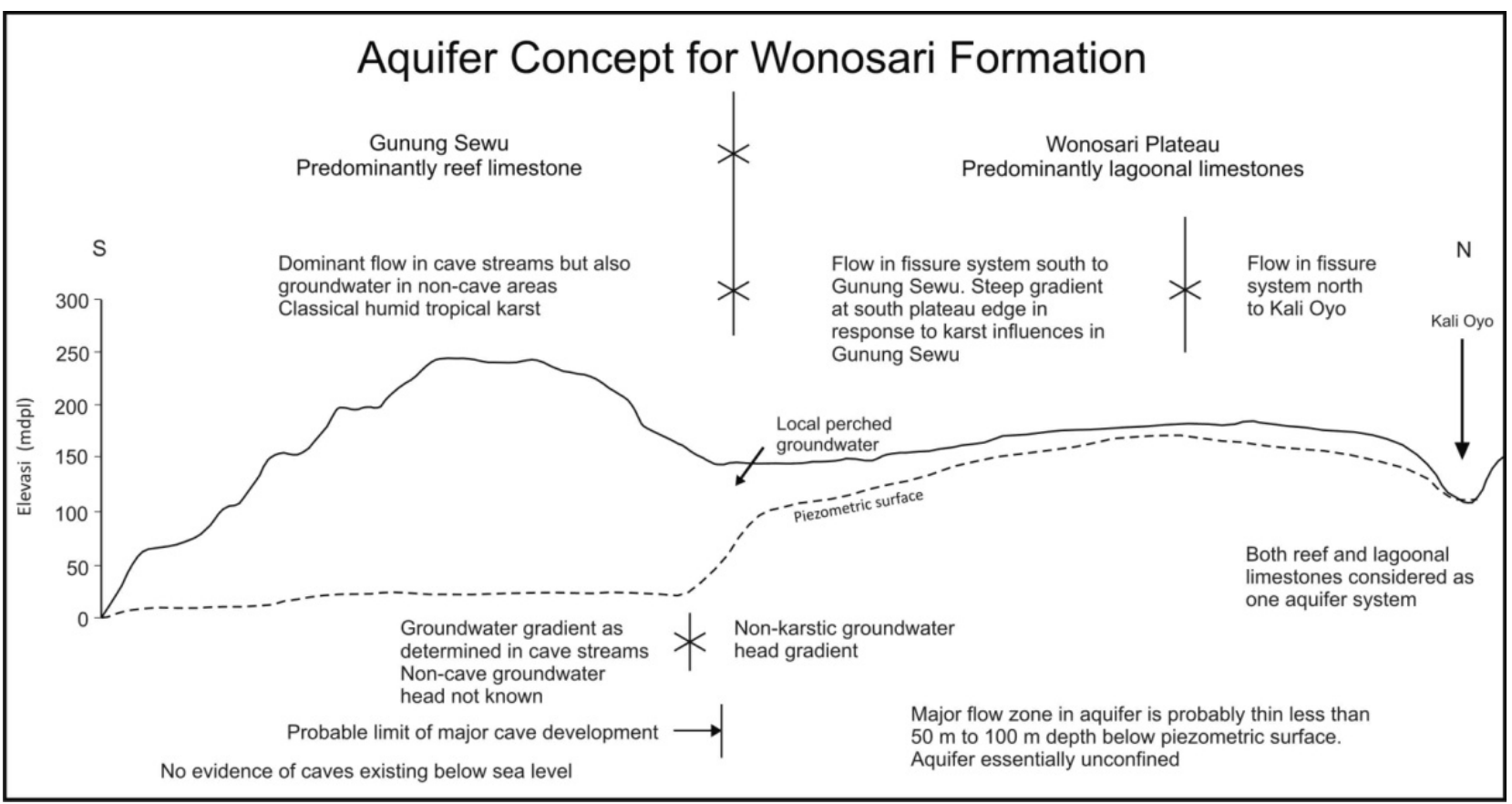

Figure 2: Cross section of aquifer conceptual model of Wonosari Formation (MacDonald \& Partners, 1984). 
infiltration of rainwater toward the deeper part of which is saturated zone of karst aquifers.

Next is the vadose zone that lies deeper, the transition zone of karst aquifers. Vertically, the tip of the vadose zone will end with a limit of groundwater level. Vadose zone is often also referred to as the aeration zone or zones are not saturated with water. That is because the pores of rocks in vadose zones often contain only air. The infiltrated water will flow through the rock matrix, fissures and caves beneath the surface. According Parizek (1976, in Stevanović, 2014) water flow direction will be parallel to the fault or major fractures contained in the rock body.

Water-saturated zone is the main aquifer layer, where water will be stored in a long time span. The thickness of the saturated zone depends on several factors such as water recharge, permeability, storativity, position and size of the point of discharge, hydraulic head, strike dip of the rock layers and artificial recharge. Karstification base which mentioned before is the bottom of the karst aquifer or the end of water-saturated zone. It is difficult to locate the position of karstificatuin base and requires a long process in its determination (Stevanović, 2014).

\section{D geoelectrical survey prospection}

The 2D geoelectrical survey method is also called profiling or Horizontal Profiling but nowadays also known as electric-resistivity tomography method. For many groundwater related problems it is preferable to carry out 2D resistivity measurements instead of $1 \mathrm{D}$ soundings (Kirsch, 2009). The data which is obtained from the measurement of resistivity in two dimensions will be displayed as pseudosection along the survey line. The purpose of the 2D geoelectrical method is to determine subsurface picture both horizontally and vertically as well as the distribution of resistivity in both directions. This principle is very appropriate in the exploration of groundwater because the dimension of aquifers as drilling targets, spread along both horizontally and vertically. There are several configuration method of the survey, including Wenner Alpha, Wenner Beta, Wenner-Schlumberger and Dipole-dipole configuration.

In the Wenner-Schlumberger array, the electrode position is as same as Wenner Alpha method, but the distance between the electrode current and potential electrodes is " $n$ " times the distance of the two potential electrodes. This configuration is shown in Figure 4, the geometry factor, $k=\pi n(n+1) a$. This configuration also detects greater concentration of high resistivity below the P1-P2 electrodes. That implies, Wenner-Schlumberger configuration sensitive to changes in resistivity horizontally and vertically. According to Loke (2000), in areas that have complex geological conditions, this method will be more promising than the configuration of Wenner Alpha and Dipole-dipole. Depth investigation of this configuration is $10 \%$ deeper than the Wenner configuration with the same distance between C1-C2 electrodes. The signal strength is lower than Wenner configuration, but higher than Dipole-dipole configuration (Loke, 2000). Wenner-Schlumberger method is also able to cover Wenner configuration weakness such as bad horizontal coverage, although it is not better than Dipole-dipole configuration.

The Dipole-dipole configuration has the same electrode arrangement with Wenner Beta array, the only different is the distance between current electrodes with the potential electrodes which equals to " $n$ " times within the same second electrode (P1 to P2 or C1 to C2). The configuration can be seen in Figure 5, with the same geometry factors with $k=\pi n(n+1)(n+2) a$. The advantage of Dipole-dipole array is it provides a long horizontal exposition (Loke, 2000).

Based on Kirsh (2009), the final results of a 2D resistivity survey is a cross-section of the calculated rock resistivities along the profile line. The final result reveals from optimization-inversion process of observed data to reduce the different between calculated and measured apparent resistivity values. The cross-section of calculated rock resistivities should include the structural interpretation of the resistivity data (e.g., the boundary of fracture zones and caves).

\section{Methodology}

Field observation for geology and 2D geoelectrical survey was conducted in Kali Suci, Gunung Kidul. Kali Suci is choosen as the research area, because in this location there is an inflow and outflow of underground river building a natural bridge (see Figure 6). Geological survey 


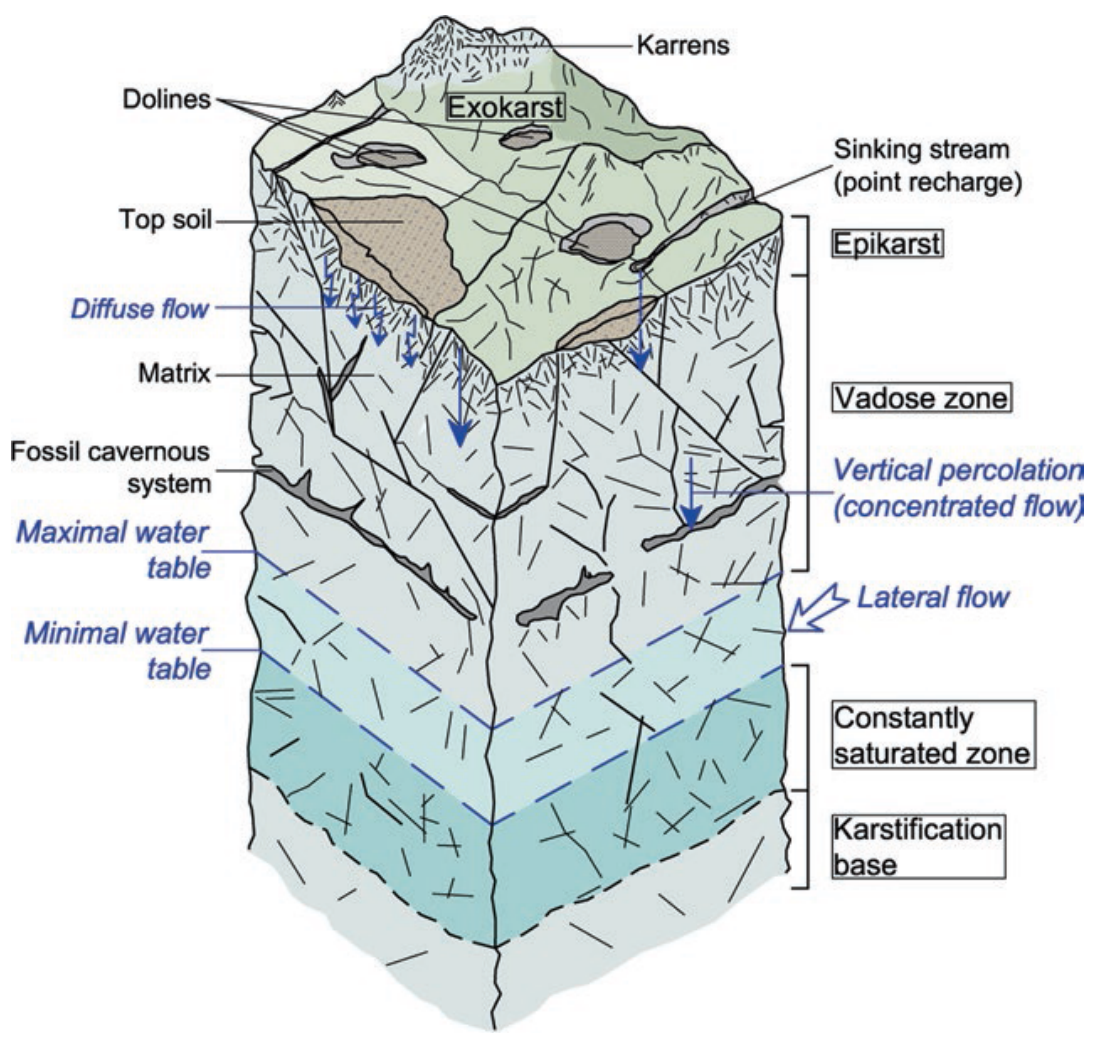

Figure 3: Schematic model of unconfined karst aquifer (Stevanović, 2014).

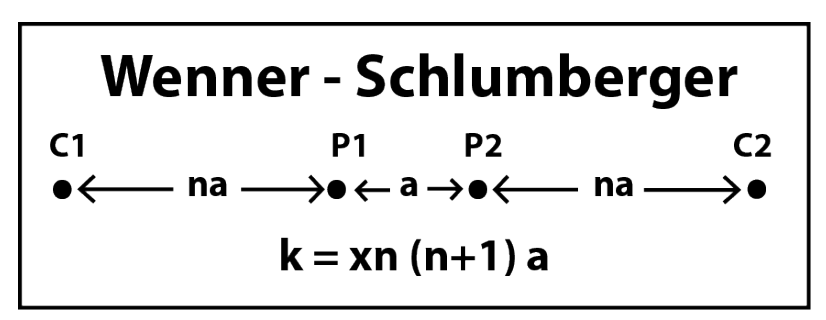

Figure 4: Wenner-Sclumberger array configuration on Geoelectrical Survey (Loke, 2000).

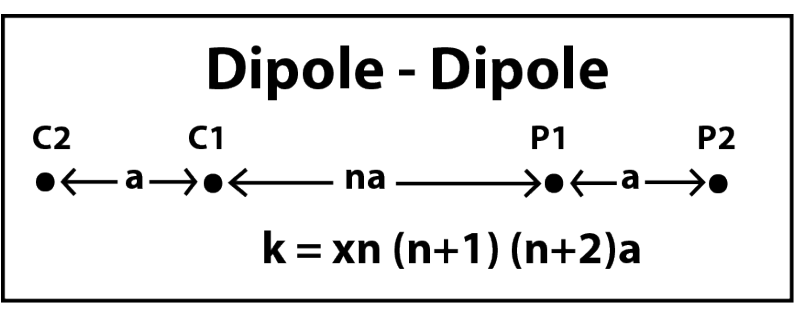

Figure 5: Dipole-dipole array configuration on Geoelectrical Survey (Loke, 2000). was conducted by applying measured stratigraphy from the bottom of river to the surface on the cave system. It is hope that different type of limestone can be identified also on the 2D geoelectrical survey. 2D geoelectrical survey by using Wenner-Schlumberger and Dipole-dipole configuration conducted parallel to the natural bridge direction and perpendicular to the underground river of karst system. The length of the geoeletric survey track is $240 \mathrm{~m}$ and the number of electrodes used are 48 electrodes. At the running time of Wenner-Schlumberger configuration the weather was clear, but it was raining when the Dipole-dipole executed. Resistivity meter used on this research is $\mathrm{McOHM}$ Model 2115. Result of measured resistivy data is optimized by conducting several inversion process to provide the final $2 \mathrm{D}$ resistivity crosssection.

\section{Results AND Discussion}

\section{Measured stratigraphy}

The outcrop which observerd for measured stratigraphy is the lythology of the cave wall in Kali Suci with a height dimension of $\pm 25 \mathrm{~m}$ and a width of $5 \mathrm{~m}$. The rocks are in the Wonosari Formation which is dominated by almost hor- 


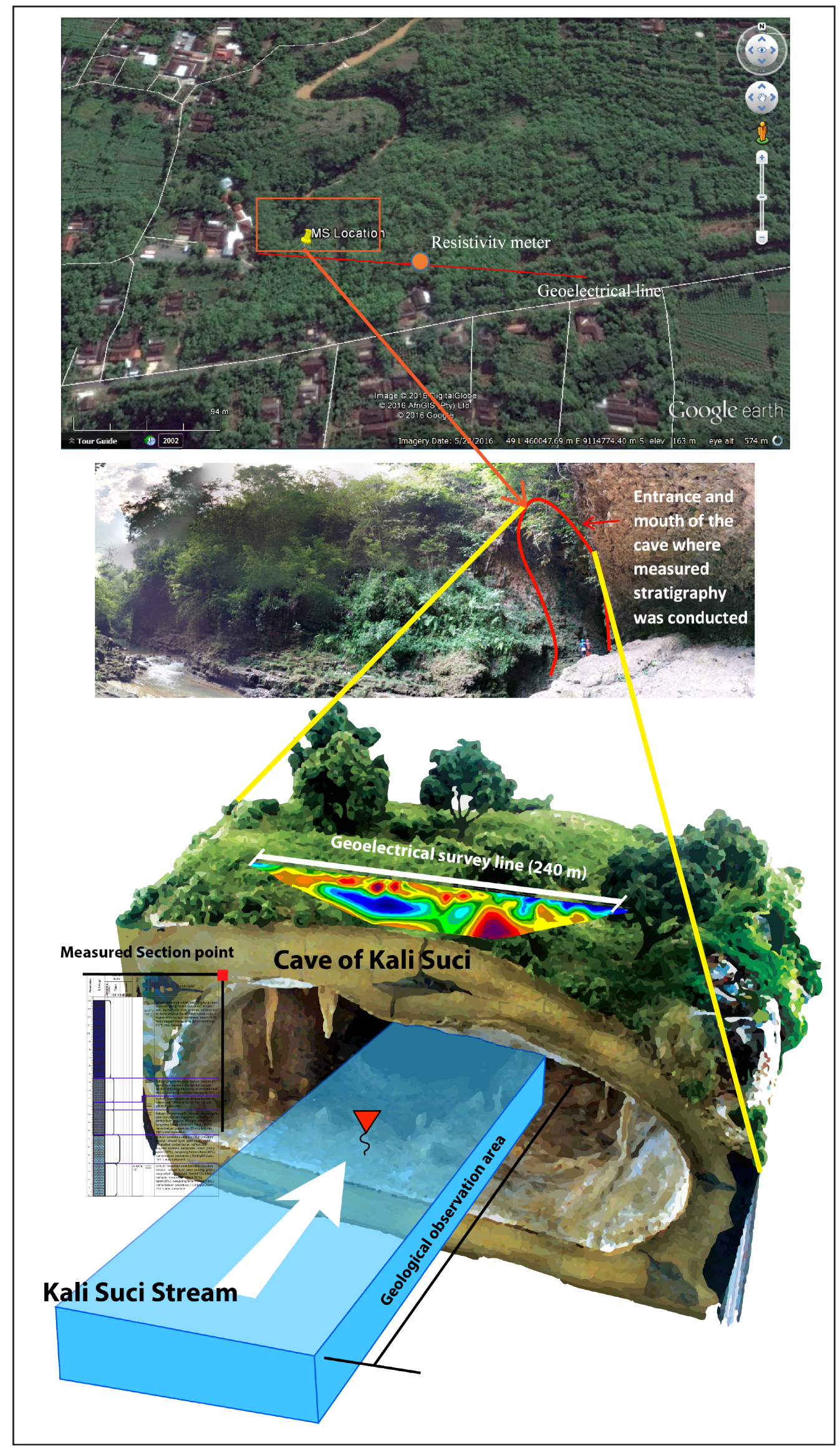

Figure 6: Data acquisition scheme of Measured Stratigraphy and 2D geoelectrical survey line in the research area. 
izontally layered limestone. The outcrop has already experienced a high degree of karstification, characterized by the discovery of crystalline limestone, the morphology of the cave itself, travertine, lapies structure, as well as the dissolution structure. According to the results of measured stratigraphy, the wall of the cave are composed by variated type of limestone, which are packstone, grainstone, wackestone and crystalline limestone. Limestone grain size varies, except when it reaches a crystalline limestone which description is limited. Limestones generally have a $\mathrm{N} 90^{\circ} \mathrm{E} / 5^{\circ}$ position. The stratigraphy sequence by its position can be separated into three parts; bottom, middle and top.

At the bottom of the cave wall of Kali Suci, the rocks are dominated by packstone and grainstone layers. The packstone and grainstone is an allochthonous limestone which have relatively fine grain sizes with small mud content. The origin of this limestone is a product of transported material, generally on the flanks of a reef body. The total thickness of the bottom layer is $50 \mathrm{~cm}$ thick. The rocks at the bottom have a clear layer and have not been perfectly karstificated (see Figure 7a).

The middle part starts from height of $1.5 \mathrm{~m}$ above the river's surface. The middle part is dominated by wackestone, categorized also as an allochthonous limestone. Wackestone has very different characteristics with type of limestone in the bottom part, marked by the significant content of carbonate mud. Contrary to packstone and grainstone, wackestone has a mud supported texture which means having a carbonate mud that dominates its rock composition. Even so, wackestone still has micrite and fossil fragments that are more than $10 \%$. The middle part is characterized by a typical sedimentary structure that is slump. The slump structure signifies a large energy deposition process, usually affected by gravity and the mass of the materials itself. The middle part thickness is approximately 3 meters (see Figure 7b).

The top (6m-23 m) wall of Kali Suci is dominated by crystalline limestone which is the result of karstification process from the previous limestone. It is characterized by the change of limestone structure that becomes hard and very massive. The limestone at the top, almost entirely transformed into calcite crystals (see Figure $7 \mathrm{k}$ ). Stalactites have occured at the roof of the cave, indicating a rapidly growing karstification process at the top of the stratigraphic sequence. Rainwater tends to be more intensive to react with the limestone at the top.

\section{D Geoelectrical survey and interpretation}

After conducting data optimization by inversion process, an error value that affect each configuration found to be $4.9 \%$ for the WennerSchlumberger configuration and $6.7 \%$ for Dipole-dipole configuration. Error value in the inversion process means calculated resistivity data may only be missed 5--7\% rather than the actual value, in other words measured resistivity data has been through a proper process. The total actual depth which achieved from the acquisition of Wenner-Schlumberger configuration is $36.9 \mathrm{~m}$, while for Dipole-dipole configuration, depth of investigation that can be achieved is $44.9 \mathrm{~m}$, or deeper compare to Wenner-Schlumberger method.

In general, Dipole-dipole configuration illustrates a similiar subsurface geological and hydrogeological condition to the 2D cross-section of Wenner-Schlumberger configuration, but unfortunately experiencing a significant vertical geometry inaccuracy. Dipole-dipole subsurface image of Kali Suci tend to be more flat than it should be, so the measured stratigraphic and geomorphological data which are a precise surface data can not be compared and patched to Dipole-dipole 2D cross section. Geological objects that occupy a certain depth shifted from its position and being in places that are not supposed to. Example, water-saturated rock that should be encountered at depths greater than $20 \mathrm{~m}$, hence the 2D cross section of Dipoledipole configuration placed the zone at depth of $11-17 \mathrm{~m}$ on a point 80 meters from the initial electrode. Nevertheless, horizontal resistivity significant contrast illustrates the presence of air that fills the upper part of the cave at the $65-70 \mathrm{~m}$ point from the initial electrode (see Figure 8 ).

Furthermore, the Dipole-dipole configuration mapped out the low resistivity of layering limestone at the bottom of the zone very well. At the bottom of the cross-section, the layers of limestone illustrated firmly and ended with 

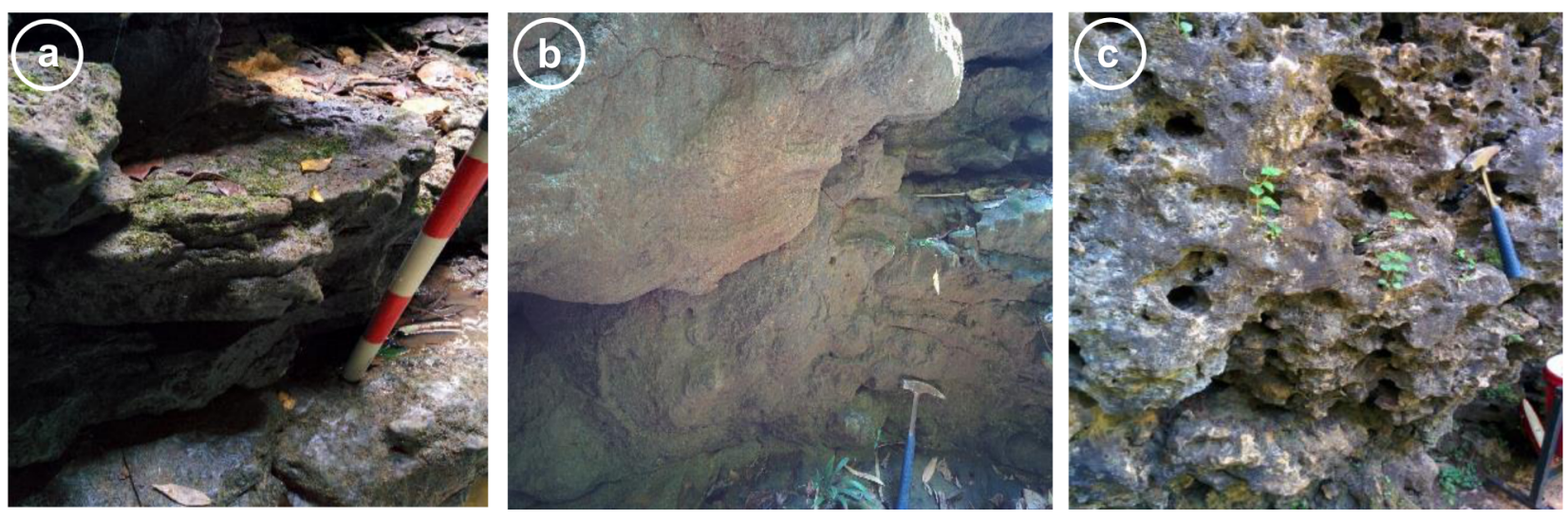

Figure 7: Carbonate rocks in the Kali Suci Cave: (a) packstone unit on bottom part, (b) wackestone unit with slump structure on the middle part, and (c) crystalline limestone unit with lapies structure on the top of the cave.
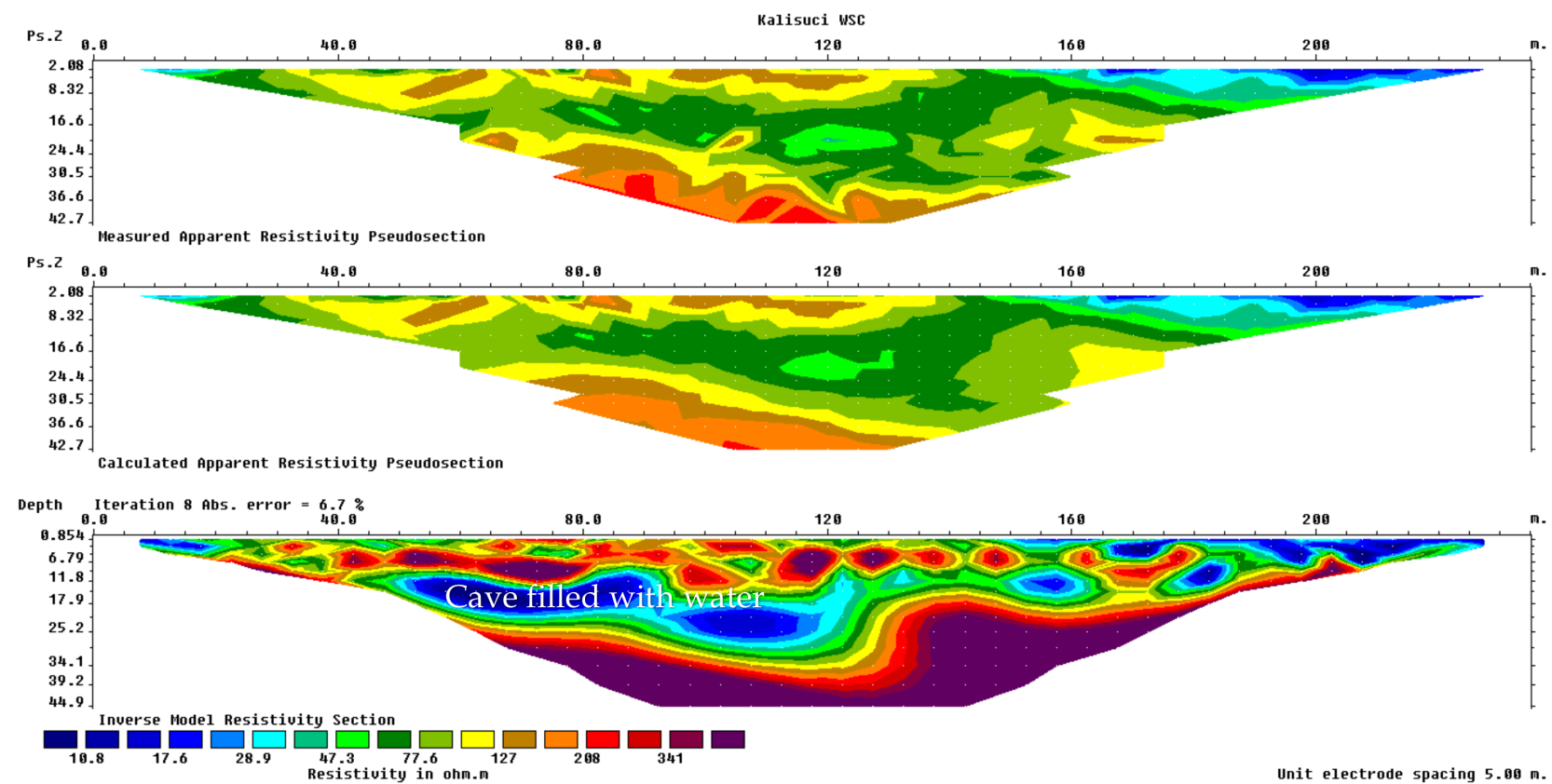

Figure 8: Cross-section of resistivity measurement and inversion result of Kali Suci with DipoleDipole configuration. 
highly resistive bedrock and kind of solid, more than $341 \mathrm{ohm} . \mathrm{m}$. The resulting resistivity range of Dipole-dipole is wider and more varied than the cross section of the Wenner-Schlumberger configuration (see Figure 9).

Distinct from the Dipole-dipole configuration result, measured stratigraphic data can be overlaid on the Wenner-Schlumberger 2D cross sections at about $65-70 \mathrm{~m}$ from the first electrode placement, thus this overlay process is matched each other. The thickness of the layer of rocks that can be measured is about $23 \mathrm{~m}$ from the top of the cave in Kali Suci downstream. The inversion result of data acquired by Wenner-Schlumberger configuration is suited better to the geological conditions of Kali Suci. Grainstone-wackestone in dry condition has resistivity range 47.3 to $77.6 \mathrm{ohm} . \mathrm{m}$. Packstone resistivity ranges $28.9-47.3 \mathrm{ohm} . \mathrm{m}$. Furthermore, the solid and massive crystalline limestone which is unable to store water in the pores and can not drain groundwater, has resistivity range between 127--208 ohm.m. For resistivity in $2 \mathrm{D}$ cross section that span exceeds 208-341 ohm.m interpreted as free air in the hollow part of the cave. In contrast to the very low resistivity 10.8 ohm.m and surroundings can be interpreted as water zone filling the cave system (See Figure 9).

\section{CONCLUSION}

Based on the fact found in the result and discussion, there are several conclusions can be made regarding the objective of the research; (1) Both configuration method of measurements can detect the existing of cave in the study area, including whether the cave fill with water or fill with air, (2) the Wenner-Schlumberger method (4.9\% RMS error) detect the exposed cave successfully to $23 \mathrm{~m}$ depth below the surface in range $65-70 \mathrm{~m}$ of the survey line with geometry $5 \times 20 \mathrm{~m}$, (3) Geoelectrical measurements in Kali Suci determine resistivity of packstone 28.9 to $47.3 \mathrm{ohm} . \mathrm{m}$, grainstone and wackestone 47.3 to $77.6 \mathrm{ohm} . \mathrm{m}$, crystalline limestones 127--208 ohm.m, groundwater from 10.8 to $17.6 \mathrm{ohm} . \mathrm{m}$ and air-filled cave 208 $>341$ ohm.m, (4) the Wenner-Schlumberger configuration reveals a better vertical geometry accuracy compared to measurement result from the Dipole-dipole method.

\section{ACKNOWLEDGEMENTS}

Authors would like to express our deep appreciation and indebtedness particularly to the following: Kali Suci management for granting the permission to conduct the survey, Mr. Djoko Riyanto and Suhari for their support in the field and designing the survey, Mr. Jaingot Parhusip for the effort to modify the resistivity meter and the last but not least Geological Department of Universitas Gadjah Mada for providing every needs to conduct this survey.

\section{REFERENCES}

Hastuti, M.S. (2015) Geokimia Air Tanah Kawasan Karst di Gunung Kidul, Skripsi, Departemen Teknik Geologi, Fakultas Teknik, Universitas Gadjah Mada, Yogyakarta (Not published).

Kirsch, R., (Ed). (2009) Groundwater Geophysics: A Tool For Hydrogeology, Springer, Berlin.

Kusumayudha, S.B., (2000) Hidrogeologi Karst dan Geometri Fraktal di Daerah Gunung Sewu, Adicita Karya Nusa, Yogyakarta.

Kusumayudha, S.B. (2004) Mengenal Hidrogeologi Karst, Yogyakarta, Pusat Studi Karst, Yogyakarta.

Loke, M.H. (2000) Electrical Imaging Surveys for Environmental and Engineering Studies : A Practical Guide to 2D \& 3D Surveys.

MacDonald \& Partners (1984) Greater Yogyakarta Groundwater Resources Study, Overseas Development Administration London, Directorate General of Water Resources Development Project (P2AT), Ministry of Public Works, Goverment of the Republic of Indonesia.

Nugroho, B., and Sukiyah, E. (2016) PhysicalMechanical Characteristics of Limestone and Underground Rivers Mapping to Support the Development of Micro-Hydro Installation in Karst Land Forms Case Study: Cave Seropan, Gunung Kidul, Indonesia., FIG Working Week 2016, Christchurch.

Stevanović, Z. (2014) Karst Aquifers: Characterization and Engineering, Springer, Swiss. Surono, Toha, B., and Sudarno. I. (1992) Peta Geologi Lembar Surakarta-Giritontro, Pusat Penelitian dan Pengembangan Geologi, Bandung.

Van Bemmelen, R.W. 1949. The Geology of Indonesia Vol 1A, Government Printing Office, The Hauge, Amsterdam.

Zhou, W., Beck, F., and Adams, A. (2002) Effective Electrode Array in Mapping Karst Hazards In Electrical Resistivity Tomography, Annealing Optimization for Inversion of First Arrival Times. Bulletin of the Seismological Society of America vol.84 (5), pp. 1397-1409. 


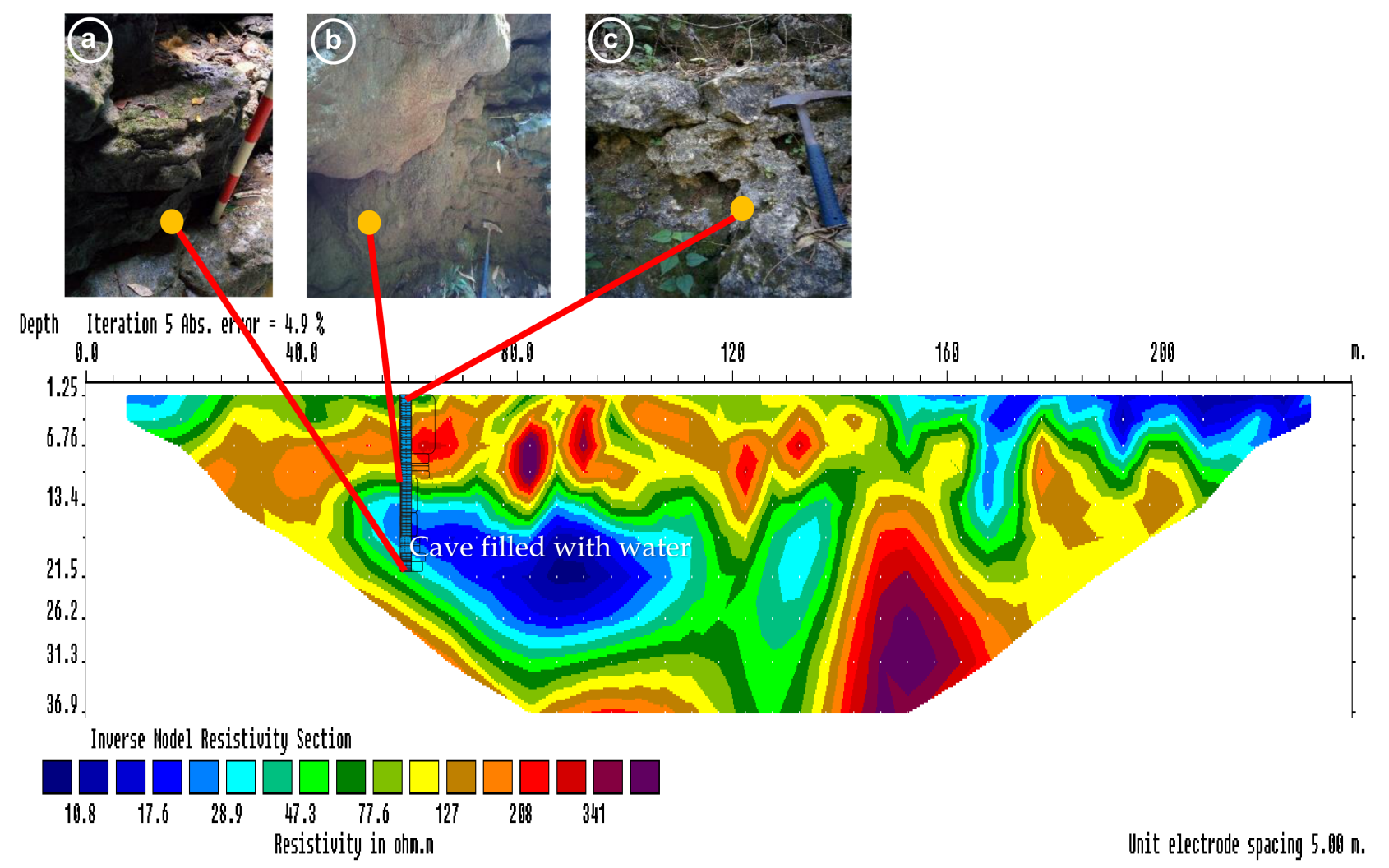

Figure 9: Cross-section of resistivity inversion result of Kali Suci with Wenner-Schlumberger configuration which has been overlaid with measured stratigraphy data. a) packstone-grainstone, b) wackestone, c) crystalline limestone. 